\title{
Tanggung Gugat hukum Perusahaan akibat pengelolaan Pertambangan Batubara
}

\author{
Oleh
}

Siti Kotijah*

\begin{abstract}
ABSTRAK
Tanggung gugat perusahaan akibat pertambangan batubara terjadi karena adanya kerusakan/pencemaran lingkungan hidup sekitar pertambangan. Akibat perusakan/ pencemaran pertambangan batubara yang dilakukan perusahaan batubara mengakibatkan kerugian bagi masyarakat. Bentuk tanggung gugat hukum untuk kerugian, merujuk pada keperdataan. Upaya hukum tanggung gugat untuk kerugian mengacu pada Pasal 1365 $B W$ melalui Pengadilan Negeri setempat.
\end{abstract}

Kata Kunci: Tanggung gugat, Perusahaan, Environmental (lingkungan), Tambang batubara

\section{Latar Belakang}

George W.(Rock) Pring, menyebutkan bahwa terdapat 2 (dua) perkembangan penting yang terjadi dalam usaha pertambangan dan hubungannya dengan program sumber daya alam oleh pemerintah diseluruh dunia. Salah satu bersifat positif, yang lainnya bersifat problematika. ${ }^{1}$ Kecenderungan pertama adalah sangat terbukanya kesempatan internasional untuk mengembangkan pembangunan sumber daya mineral (bahan tambang). Kedua, adalah tumbuhnya tantangan yang terkait dengan produksi, produk, dan pembangunan pertambangan. Secara alami bahwa

${ }^{*}$ Fakultas Hukum Universitas Mulawarman, fafa_ law@yahoo.com

1 George W (Rock) Pring, Mining Enviroment and Development, A Series of Paper Prepared for the United Nations Conference on Trade and Development (UNCTAD), tt, h.5. pertambangan menyebabkan gangguan terhadap lingkungan, sosial, budaya dan ekonomi. ${ }^{2}$ Kegiatan usaha pertambangan dan lingkungan hidup adalah 2 (dua) hal yang dapat dipisahkan, ${ }^{3}$ pertambangan penting bagi kehidupan bernegara untuk meningkat kesejahteraan warga dan pertambangan

\footnotetext{
2 Ibid.

3 Dua hal yang tidak dapat dipisahkan, bahkan ada ungkapan " tiada kegiatan usaha pertambangan tanpa pengrusakan/pencemaran lingkungan hidup". Meskipun kedua hal tersebut, tidak dapat dipisahkan karena keterkaitan (Interdepenecy), tetapi pengaturanya tetap terpisah dan bahkan tersebar dalam berbagai peraturan perundang-undangan. Hal ini perbedaan prinsip hukum sumber daya alam dan hukum lingkungan yang mempunyai asal-asul yang berlainan, bahkan bertentangan satu sama lainnya. Hukum sumber daya alam lebih pada eksploitasi, sedangkan hukum lingkungan pada pelestariannya. Meskipun kedua hukum kelihatan bertentangan, tetapi selalu berkaitan satu dengan lainnya, hubungan yang demikian dapat dilihat sebagai dua sisi dari sekeping uang logam, John W Head, 1997, Pengantar Umum Hukum Ekonomi, Edisi Bahasa Indonesia dan Inggris, ELIPS, Jakarta, h. 56-57.
} 
berdampak kerusakan terhadap lingkungan. Secara mendasar dijamin negara, atas hak menguasai negara atas kekayaan sumber daya alam oleh negara termuat dalam Pasal 33 ayat (3) UUD 1945 yang berbunyi: "bumi dan air dan kekayaan alam yang terkandung didalamnya dikuasai oleh negara dan dipergunakan untuk sebesarbesarnya kemakmuran rakyat. Ketentuan pasal 33 ayat $3,{ }^{4}$ dapat diartikan dalam hubungan antara negara dengan bumi, air dan kekayaan alam yang terkandung didalamnya adalah hubungan penguasaan. Artinya bumi, air, dan kekayaan alam yang terkandung didalamnya itu dikuasai oleh negara dan dipergunakan untuk sebesar-

${ }^{4}$ Sejarah terbentuknya Pasal 33 ayat 3 UUD 1945, berawal pada saat R. Soepomo melontarkan idenya didepan sidang Badan Penyidik Usaha Persiapan Kemerdekaan Indonesia (BPUKPI) pada tanggal 1 Mei 1945, yang diakhir pidatonya tentang negara integralistik antara lain menyebutkan:

Sekarang tentang hubungan antara negara dan perekonomian. Dalam negara yang berdasar integralistik, yang berdasar persatuan, maka dalam lapangan ekonomi akan dipakai sistem "sosialisme negara (staats socialisme). Perusahaan-perusahaan yang penting akan diurus oleh negara sendiri, akan ditetapi pada hakekatnya negara yang akan menentukan dimana dan dimasa apa atau perusahaan apa yang akan diselenggarakan oleh pemerintah pusat atau pemerintah daerah atau yang akan diserahkan kepada suatu badan hukum privat atau kepadaa seseorang, itu semua tergantung daripada kepentingan negara, kepenting rakya seluruhnya. Dalam negara Indonesia baru, dengan sendirinya menurut keadaan sekarang, perusahaan-perusahaan sebagai lalu lintas, electriciteit, perusahaan alas rimba harus diurus oleh negara sendiri. Begitupun tentang hal tanah, pada hakekatnya negara yang menguasai tanah seluruhnya. Tambang-tambanng yang penting untuk negara akan diurus oleh negara sendiri. Melihat sifat masyarakat Indonesia sebagai masyarakat pertanian, maka dengan sendirinya tanah pertanian menjadi lapangan hidup dari kaum tani dan negara harus menjaga supaya tanah pertanian itu tetap oleh kaum tani. ( Risalah Sidang Badan Penyidik usahaUsaha Persiapan Kemerdekaan Indonesia (BPUPKI), Panitia Persiapan Kemerdekaan Indonesia (PPKI) 29 Mei 1945-19 Agustus 1945, Seketariat Negara Republik Indonesia, 1992, h..35. besarnya kemakmuran rakyat, termasuk dalam hal kekayaan sumber daya alam berupa mineral dan batubara.

Pengelolaan pertambangan batubara berkelanjutan yang berdasarkan pada lingkungan hidup adalah suatu kebutuhan mutlak. ${ }^{5}$ Usaha pertambangan harus berjalan seimbang dengan upaya perlindungan dan pengelolaan lingkungan hidup dengan cara mengembangkan pengelolaan pertambangan yang berbasis lingkungan.

Salah satunya pembangunan pengelolaan pertambangan batubara saat ini, yang menimbulkan dampak lingkungan akibat pencemaran lingkungan, sebagai contoh yang terjadi di Kota Samarinda. Pencemaran lingkungan ${ }^{6}$ yang dilakukan PT. Nuansa Coal Invesment telah, dalam kasus pencemaran lingkungan disekitar warga. Settling pond belum memadai, sehingga pengelolaan limbah mencemari sumur warga. Pencemaran lingkungan yang terjadi mengakibatkan pada penderitaan bagi masyarakat sekitar pertambangan dalam kehidupanya. Kerugian yang ditimbulkan akibat pertambangan batubara, dalam hal ini berakibat hukum terhadap pertanggungjawaban kepada perusahaan pemegang izin usaha pertambangan. Kerusakan/pencemaran akibat pertambangan batubara. Tanggung gugat perusahaan dalam keperdataan, berkaitan

${ }^{5}$ Hal ini disebabkan usaha pertambangan, selalu diikuti dengan terjadi pengrusakan dan pencemaran lingkungan pada kawasan sekitar pertambangan.

${ }^{6}$ Pencemaran lingkungan akibat pertambangan batubara di Kota Samarinda, dari data BLH Kota Samarinda, untuk tahun 2013, sudah ada lebih 10 yang mendapat peringatan untuk melakakukan perbaikan lingkungan. 
dengan gantirugi terhadap masyarakat yang mengalami kerusakan/pencemaran akibat pertambangan batubara.

\section{Rumusan Masalah}

Usaha pertambangan batubara menimbulkan dampak pencemaran lingkungan bagi masyarakat sekitar tambang dan kerugian. Tuntutan gantirugi dilakukan dengan melakukan tanggung gugat perusahaan pertambangan batubara Terhadap pencemaran lingkungan. Apa tanggung gugat perusahaan terhadap dampak pencemaran lingkungan akibat pertambangan batubara.

\section{Pembahasan Tanggung Gugat}

Dalam perbuatan terhadap pencemaran lingkungan, dalam pengertian bahwa semua perbuatan pengusaha dalam pertambangan dalam melaksana usaha pengelolaan pertambangan batubara harus dapat dipertanggungjawabkan secara hukum, termasuk dengan segala konsekuensinya untuk dikenakan sanksi hukum terhadapa pelanggaran norma-norma hukum yang mendasari. Dalam beberapa istilah tanggunggugat, menurut Agus Yudha Hernoko, ${ }^{7}$ tanggung gugat adalah suatu rangkaian untuk menanggung kerugian yang diakibatkan karena kesalahan atua resiko. Hal tersebut juga dijelaskan oleh Y. Sogar Simammora,${ }^{8}$ bahwa tanggung gugat tidak

\footnotetext{
7 Agus Yudha, Kuliah Teori-teori Tanggung Jawab Hukum dan Tanggung Gugat, tanggal 25 Oktober 2010, Program Studi Doktor Ilmu Hukum, Fakultas Hukum, Universitas Airlangga.

${ }^{8}$ Tanggung gugat mengandung esensi untuk membayar sejumlah ganti rugi karena kesalahan yang dilakukan. Kesalahan itu dapat bersifat murni dalam koridor Pactum de Contrahendro (PC) atau kesepakatan
}

hanya berupa ganti kerugian, namun juga pemulihan kepada keadaan semula, Y.Sogar Simamora ${ }^{9}$ mengemukakan, inti dari suatu perbuatan melanggar hukum (onrechtmatige daad), yaitu tidak ada hubungan kontratual antara pihak dengan pihak lainnya. Perbuatan melanggara hukum terjadi apabiila salah satu pihak merugikan pihak lain dengna suatu kesengajaan ataupun ketidaksengajaan dan menimbulkan kerugian pada salah satu pihak.

MenurutJ.H. Nieuwenhuis, ${ }^{10}$ tanggung gugat timbul karena adanya perbuatan melanggar hukum (onrehmatige daad) dan merupakan penyebab (oorzaak) timbulnya kerugian. Sedangkan pelakunya bersalah (schuld), maka orang itu harus bertanggug gugat atas kerugian tersebut. Hal ini juga selaras denga pendapat Marthalena Pohan, yang mengemukakan suatu tanggung gugat karena ada suatu unstfout. ${ }^{11}$

pendahuluan, dalam pengertian kesalaha terjad pada tahap negoisasi tetapi tidak berlanjut pada penutupan kontrak, ini jenis culpa in contrahendo, pada terkait tanggung gugat PC dalam Acricle 154 German Civil Code (BGB) Yohanes Sogar Simamora, Kuliah Perbandingan Hukum Perdata, tanggal 26 Oktober 2010, Program Doktor Ilmu Hukum, Fakultas Hukum, Universitas Airlangga. Lihat Karekteristik Pactum De Contrahendo, Ibid, h.123.

9 Ibid.

${ }^{10}$ J.H. Nieuwenhuis, Hoofdstuken verbintenissenrecht, terjemahan Djasadin Saragih, Surabaya, 1985, h.118.

11 Menurut Marthalena Pohan, Tanggunggugat Advokat, Dokter, dan Notaris, Bina Ilmu, Surabaya, 1985, h.21-22. Lebih lanjut mengemukakan kesalahan yang dilakukan dalam mejalankan jabatan-jabatan khusus dan tertentu seperti dokter, advoat, dan notaris, dapat menimbulkan tanggung gugat ada 2 (dua) macam kesalahan, yaitu:

1. Kunsfout, yaitu kesalahan yang disebabkan kesengajaan atau kesalahan yang berat. Contoh apabila seorang dokter memberikan suntikan cairan yang salah menyebabkan kematian seorang pasien. Atua seorang notaris dalam membuat akta tidak berpedoman pada peraturan-peraturan yang berlaku dalam pembuatan akta, sehingga akta menjadi titik ontentik atau batal; dan 
Dangan demikian setiap kewenangan yang sah baik bersumber dari undang-undang maupun perjanjian, dapat menimbulkan tanggung jawab pada si pelaksana tugas atau kewajiban itu. Dalam Black's Law Dictinary," dinyatakan: "Liability is the quality or state of being legaly obligated or accountable; legal resposibility to another or to society, enforceable by civil remedy or criminal punishment (liability for injures coused by negligence)-also termed legal liability.

Pasal 1365 BW tanggung gugat berdasarkan perbuatan melawan hukum, juga kepada kesalahan pada si pembuat. ${ }^{13}$ Tanggung gugat tanpa kesalahan, suatu hal yang didalam beberapa undangundang asing diatur sebagaimana harusnya (tanggung gugat asal orang yang bersangkutan mempunyai cukup daya pikul finansiil dan kerugiannya tidak dapat dituntut penggantinya daripda pihak ketiga yang berkewajiban untuk mengawasi). ${ }^{14}$

2. ${ }^{B}$ eroepsfout yaitu kesalahan-kesalahan biasa, contoh seorang notaris menolak melakukan tugas jabatan tanpa alasan yang dapat diterima, sehingga dengan demikian tidak menempati kewajiban selaku notaris.h. 11-13. Lihat ringkasan Ghansham Anand, Karakteristik Jabatan Notaris di Indonesia dan Batas Tanggung Gugatnya, Program Doktor Fakultas Hukum Universitas Airlangga Surabaya, 2013, h.11.

${ }_{12}$ Henry Campbell Black, Black's Law Dictionary, West Publishing, Co.St, Paul Minnessotta, 1990, h.. 225.

${ }_{13}$ Syarat kesalahan, dalam artian subjektif atau abstrak, tetapi dalam objektif atau konkrit. Dalam hal ini apakah pembuat pada umumnya adalah" toerekeningsvatbaar" (dapat pertanggungjawabkan), artinya apakah ia pada umumnya menginsafi akibat-akibat dari pada perbuatan-perbuatannya. Misalnya pada anak kecil dan orang sakit jiwa yang tidak dapat dianggap adanya tanggung gugat.

${ }^{14}$ Sri Soedewi Masjcchoen Sofwan, Hukum Perdata; Hukum Perutangan, Bagian B, Seksi Hukum Perdata Fakultas Hukum Univeriverstas Gajah Madha, Yogjakarta, 1980, h. 59. Selanjutnya di mengemukakan faktor kesalahan ada 2 (dua) istilaj yakni:
Pasal 1365 orang yang menimbulkan kerugian bertanggung gugat hanya apabila ia bersalah. Apa yang diartikan kesalahan. ${ }^{15}$ Menurut Philipus M. Hadjon Pasal 1365 BW dapat sebagia peraturan yang berlaku baik dalam suasana hukum perdata maupun hukum publik, yakni: ${ }^{16}$

a. ${ }^{\text {orang yang dirugikan itu sendiri mempunyai }}$ kesalahan tentang kerugian yang terjadi (faulte commune” atau “faute partagee');

b. Kerugian yang disebabkan oleh pembuat lebih dari pada seorang.

Contoh arrest tahun 1916 (HR 4 Februari 1916 W. 9919, NJ 1916 h.450, Hoetink No.109, dalam putusan pengadilan, bahwa jika orang yang dirugikan itu sendiri mempunyai kesalahan juga terhadap kerugian yang ditimbulkan, maka ia harus dibebani dengan sebagian daripada kerugian itu, kecuali jika perbuatan yang melawan hukum itu dilakukan dengan sengjaja. (HR 11 Maret 1938 NJ 1939 Nomor.128 EMM). Hoge Raad, menyatakan bahwa" jika kerugian itu disebabkan oleh karena lebih daripda seorang yang melakukan perbuatanperbuatan, maka kerugian itu dapat untuk seluruhnya dituntut penggantinya dari pada masing-masing mereka yang bertanggung gugat untuk salah satu perbuatan itu (HR.30 Oktober 1925, W 11444 MFF, NJ 1926 h. 157, PS, Hoetink Nomor 113). Ini menjadi tanggung gugat sudut luar, antara mereka sendiri orang-oran yang bertanggung gugat itu dapat saling menuntut pengganti, sekedar yang dibayarkan lebih daripada yang sepadan dengan bagian mereka dalam kesalahannya. Ibid, h.59.

${ }^{15}$ Dalam ini contoh kesalahan A menyebengi jalan tanpa memperhatikan lampu merah untuk para pejalan kaki. Usaha (yanag berhasil) untuk menghindari A, pengendaraan mobil B menabrak tiang rambu lalu lintas (kerugian Rp.50.00, 00). Dalam analisa A bukan hanya melanggar hukum, disamping melakukan kesalahan, J.H. Nieuwenhuis, Hoofdstukken Verbintenissenrecht, atau Pokok-Pokok Hukum perikatan, Terjemahan Djasadin Saragih, 1985. h. 67.

16 Philipus M. Hadjon, Pengertianpengertian dasar tentang tindak pemerintaahan, Stensil, Djumali, 1985, h.165. Pendapat ini juga dikemukakan Indroharto, pemerintah dalam melaksanakan tugasnya tidak jarang menggunakan norma hukum peserta, sehingga seringkali mengeluarkan keputusan-keputusan yang melahirkan atau ditujuhkan untuk dilakukannya perbuatan hukum perdata yang jangkuannya agar dilakukan suatu hukum perdata. Keputusan-keputusan tata usaha negara yang demikian ini tidak jarang mengakibatkan ikut dipertanggungjawaban harta kekayaan badan hukum (publik) untuk yang berkedudukan sebagai badan hukum pedata., lihat Indroharto, Perbuatan Pemerintah Menurut Hukum Publik dan Hukum Perdata, Lembagan Litbang, Hukum Administrasi Negara, 1999. h.5. 
Pemerintah lebih suka menggunakan lembaga-lembaga hukum yang tersedia dalam lapangan hukum perdata dengan segala macam bentuk variasinya. Hal ini disebabkan karena dengan sarana yang ada tersedia dalam suasana hukum perdata terutama lembaga kebebasan berkontrak banyak sekali kemungkinan yang dapat direalisasi daripada kalau menggunaakan ketentuan hukum publik.

\section{Tuntutan Ganti Rugi Atas Dasar Perbuatan Melanggar Hukum}

\section{Istilah onrechmatige daad dalam} bahasa Belanda lazimnya mempunyai arti yang sempit, yaitu arti yang dipakai dalam Pasal 1365 BW dan hanya berhubungan dengan penafsiran dari pasal tersebut. Sedangkan istilah "perbuatan melanggar hukum" ditujuhkan kepada hukum yang pada umumnya berlaku di Indonesia dan sebagian tersebut merupakan hukum adat. ${ }^{17}$ Pasal 1365 BW menyatakan: setiap perbuatan melawan hukum yang oleh karenanya menimbulkan kerugian pada orang lain, mewajibakan orang yang karena kesalahannya menyebabkan kerugian itu mengganti kerugian..

\section{Dalam BahasaIndonesia"onrechmatige} daad adalah "perbuatan melanggar hukum"18

${ }^{17}$ Wirjono Prodjodikoro, Perbuatan Melanggar Hukum di Pandang Dari Sudut Hukum Perdata, Mandar Maju, Bandung, 2002, h. 1.

${ }_{18}$ Onrechmatige daad, dalam hukum Romawi dan hukum Belanda Kuno, belum dikenal gugat berdasarkan onrechmatige daad. Namun di peundang-undang Perancis, Code Civil (C.C) Pasal 1382 "Tout fait quelcongue de $i$ 'homme qui cause a autrui un dommage, oblige celui par la faute de wuell it est arrive a le reparer. Lihat AsserRutten, Verbinttensisenrcht, De verbintenis uit de wet, Cetakan IV, Tjeenk Willink, Zwollen, 1975, h.48. lihat Soetojo Prawirohamidjojo, Perbuatan Melanggar Hukum Oleh Pengusaha (Onrechtmatige Overheiddaad), h..47. bukan perbuatan melawan hukum" karena istilah "melawan hukum"19 dalam

Pasal ini diambil ahli Nederland dan dimasukand alam BW Pasal 1401. Pasal tidak saja disalin Letterlijk, namun juga itilah "onrechmatige" didepan "daad" anjuran Caret Asser seorang Komisi Redaksi Undang-undang Nasional Nederland. Rancangan undang-undang 1924 didepan istilah"daad" dan ditempat istilah "wederrechtlijke" oleh beberapa aggota Tweede Kamer. Kemudiian istilah "wederrecitelijk" diubah "onrechmatige". Menurut Hoge Raad (H.R) Arrest tahun 1863 memberikakan pengertian "onrechmatige" sebagia perbuatan yang bertentangan dengan kewajiban menurut undang-undang. Kemudian 1883, putusan H.R tahun 1863 menambah dengan katakata" perbuatan yang melanggar hak orang lain menurut undang-undang (inbruek op eens onders geschreven rech, sehingga onrechmatige adalah 1) perbuatan yang melanggar kewajiban menurut undang-undang, dan 2) perbuatan yang melanggar hak orang lain dalam undangundang. Ada beberapa kasus terkait diatas, Arrest H.R tanggal 6 Januari 1905 dengan nama Singer Naiimachine Arrest dan arrest H.R tanggal 10 Juni 1910 dengan Zutphense Juffrouw Areest, ini dikategori onrechmatige dalam arti sempit. Onrechmatige dalam arti luas, pada perkara Lindenbum-Cohen yang diputus H.R, tanggal 31 Januari 1919.

19 Pengertian melawan hukum dalam Undang-undang No.31 Tahun 1999 tentang Pemberantas Tindak Pidana Korupsi jo Undang-undang No.20 Tahun Perubahan atas Undang-Undang No.31 Tahun 1999 tentang Pemberantasan Tindak Pidana Korupsi selanjutnya disebut UU PTPK. Terkait dengan Putusan MK No:003/PUU/-IV/2006 tanggal 24 Juli 2006, pengertian melawan hukum dalam Pasal 2 (1) UU PTPK bertentangan dnegan UUD 1945, dan penjelasan Pasal 2 ayat (1) tidak mempnyai kekuatan hukum mengikat, dalam putusannya unsur melawan hukum (wedeechtelijkheid), antara lain sebagai berikut:

Pasal 2 (1) UUPTPK memperluas kategori unsur melawan hukum dalam hukum pidana, tidak algi hanya formale wedeechtelijkheid) melainkan juga dalam arti materiele wedeechtelijkheid. Penjelasan Pasal 2 (1), kalimat bagian pertama, berbunyi" yang dimaksud dengan secra melawan hukum dalam pasal ini mencakup perbuatan melawan hukum formil maupun dalam arti materiil, yakni meskipun perbuatan tersebut tidak diatur dalam perundang-undangan, namun apabila perbuatan tersebut dianggap tercela karena tidak sesuai dengan rasa keadilan tersebut dapat dipidana; dan

Perbuatan yang tidak diatur dalam perundangundangan secara formil, yaitu pengertian yang bersifat onwetmatig, namun secara formil yaitu dalam pengertian yang bersifat masyarakat, yaitu norma-norma sosial yang memandang suatu perbuatan sebagai perbuatan tercela menurut norma sosial tersebut, dimana perbuatan tersebut dipandang telah melanggar kepatutan, kehati-hatian dan keharusan yang dianut dalam hubungan dengan perorang dalam masyarakat, maka dipandang bahwa perbuatan tersebut telah memenuhi melawan hukum (wedeechtelijkheid). 
bahasa Belanda adalah "wederrechtelijk" sebagaimana yang tertuang di dalam Pasal 362 KUHP tentang "pencurian." “20 "onrechmatige daad pada mulanya diartikan secara sempit yaitu mengingat perkataan "onrechmatige daad" sebagai suatu perbuatan yang langsung melanggar suatu peraturan hukum. Pengertian onrechmatige daad saat ini diartikan sebagai onrechmatige daad (perbuatanmelanggarundang-undang), bilamana perbuatan tersebut bertentangan dengan undang-undang. Pengertian sempit ini sangat dipengaruhi oleh aliran legisme dalam filsafat hukum. ${ }^{21}$

Perbuatan melawan hukum di Indonesia secara normatif selalu merujuk ketentuan Pasal 1365 BW. ${ }^{22}$ Mariam Darus

Ukuran yang dipergunakan dalam hal ini adalah ukuran atau peraturan tidak tertulis. Rasa keadilan (rechtsgevoel), norma kesusilaan atau etik, dan norma-norma moral yang berlaku dimasyarakat telah cukup menjadi kreteria satu perbuatan tersebut merupakan tindakan yang melawan hukum, meskipun hanya dilihat secara materiil. Penjelasan Pasal 2 (1) tentang unsur melawan hukum, melainkan telah melahirkan norma baru, yang memuat dipergunakan ukuran-ukuran yang tidak tertulis dalam undang-undang formal untuk menentukan perbuatan yang daoat dipidana. Penjelasan Pasall 1365 BW yang dikenal dalam hukum perdata yang dikembangkan sebagai yurisprudensi mengenai perbuatan melawan hukm (onrechmatigedaad) seolah-oleh diterima menjadi satu ukuran melawan hukum dalam hukum pidana ((wedeechtelijkheid). Oleh karena itu apa yang patut dan yang memenuhi syarat moralitas dan rasa keadilan yang diakui dalam masyarakat, yang berbeda-beda dari satu daerah ke daerah lain, akan mengakibatkan bahwa apa yang disatu daerah merupakn perbuatan yang melawan hukum didaerah lain boleh jadi bukan merupakan perbuatan melawan hukum. Lihat Guse Prayudi, Sifat Melawan Hukum UndangundangPpemberantasan Tindak Pidana Korupsi, Varia Peradilan N0.244, 2007, h.27-28.

20 Peter Mahmud Marzuki, Op. Cit. h.105

${ }^{21}$ Moegni Djojodirdo, Op. Cip, h.28.

${ }^{22}$ Menurut Rosa Agustina, Perbuatan melawan hukum, Desertasi Univeritas Indonesian, Jakarta, 2003. Rumusan dalam Pasal 1365 ini unik, tidak sepertia ketentuan-ketentuan pasal lainnya. Dalam rumusan norma Pasal 1365 BW lebih merupakan struktur norma daripada
Badrulzama dalam Rancangan UU (RUU)

Perikatan berusaha merumuskan secara selengkap sebagai berikut: ${ }^{23}$

(1) Suatu perbuatan melawan hukum yang mengakibatkan kerugian kepada orang lain, mewajibakan orang yang karena kesalahan atau kelalian menerbitkan kerugian itu mengganti kerugian tersebut;

(2) Melanggar hukum adalah setiap perbuatan yang melanggar hak orang lain atau bertentangan dengan kepatutan yang harus diindahkan dalam pergaulan kemasyarakatan terhadap pribadi atau harta benada orang lain; dan

(3) Seorang yang sengaja tidak melakukan suatu perbuatan yang wajiba dilakukannya, disamakan dengan seorang yang melakukan suatu perbuatan terlarang dan karenanya melannggar hukum.

Konsep ini pengertian melawan hukum menjadi tidak hanya diartikan sebagai melawan hukum menjadi tidak hanya diartikan sebagai melawan undang-undang (hukum tertulis) tetapi juga bertentangan dengan kepatutan yang harus diindahkan dalam pergaulan masyarakat (hukum tidak tertulis)..

Bentuk tanggung gugat menurut Pasal $1365 \mathrm{BW}$ ini adalah bentuk tanggung gugat subtansi ketentuan Pasal 1365 senantiasa memperlukan materialisasi luar BW. Dilihat dari dimensi waktu ketentuan ini akan "abadi" karena hanya merupakan struktur, h. 3.

${ }^{23}$ ST. Remy Sjahdeini $d k k$, Naskah Akademik Peraturan Perundang-undangan Tentang Perbuatan Melawan Hukum, Jakarta, Badan Pembinaan Hukum Nasional, Depertemen Kehakiman RI, 1993/2994, h..18, Ibid. h...3. 
yang menekankan pada faktor kesalahan (liability based on fault), sehingga apabila pasal ini dijadikan dasar gugatan, maka pihak yang dirugikan mempunyai kewajiban untuk membuktikan adanya kesalahan yang menimbulkan kerugian itu. Pada perbuatan melanggar hukum berlaku syarat bahwa secara umum penggugat harus dapat membuktikan adanya kerugian yang diderita adalah merupakan akibat dari perbuatan melanggar hukum yang dilakukan oleh tergugat. Hal ini selaras dengan ketentuan Pasal 163 HIR, 283 Rbg dan 1865 BW.

Ketentuan Pasal 1365 BW, dalam hal ini seseorang harus bertanggung gugat atas kerugian orang lain, jika:

\section{a. Adanya suatu perbuatan}

Suatuperbuatanmelanggarhukum diawali oleh suatu perbuatan dari pelaku. Umumnya diterima anggapan bahwa dengan perbuatn disini dimaksudkan, baik berbuat sesuatu maupun tidak berbuat sesuatu, misalnya tidak berbuat sesuatu, dimaksudkan,baik berbuat sesuatu, $\mathrm{p}$ padahal dia mempunyai kewajiban hukum untuk membuatnya kewajiban mana timbul dari ketentuan hukum yang berlaku (sebab ada pula kewajiban yang timbul dari ketentuan hukum yang berlaku (sebab ada pula kewajiban yang timbul dari suatu perjanjian). Karena itu, terhadap perbuatan melanggar hukum, tidak ada unsur "persetujuan atau kata sepakat" dan tidak juga unsur “causa” yang diperbolehkan" sebagaimana yang terdapat dalam kontrak. ${ }^{24}$

b. Perbuatan tersebut bersifat melangggar hukum

Perbuatan yang dilakukan tersebt haruslah melanggar hukum. Sebagimana telah dijelaskan diata, bahwa perbuatan melanggar hukum tidak hanya melanggar ketentuan hukum yang tertulis, namun juga ketentuan yang tidak tertulis. Hal tersebut meliputi:

1) Melanggar hak orang lain;

2) Bertentangan dengan kewajiban hukum pelaku;

3) Bertentangan dengan kesusilaan;

4) Bertentangan kecermatan yang harus diindahkan dalam lalu lintas masyarakat terhadap diri dan barang orang lain.

c. Adanya kerugian kepada pihak lain

Adanya kerugian (schade) bagi korban juga merupakan syarat agar gugatan berdasarkan 1365 BW dapat dipergunakan. Berbeda dengan kerugian yang diakibatkan oleh wanprestasi yang hanya mengenal kerugian meteriil, maka kerugian karena perbuatan melanggar hukum disamping kerugian materiil, yurisprudensi

\footnotetext{
${ }^{24}$ Munir Fuady, Op. Cit, h.10-11.
} 
juga mengakui konsep kerugian immaterial, yang juga akan dinilai dengan uang. ${ }^{25}$

d. Kerugian itu timbul sebagai akibat perbuatan tersebut (hubungan kausal):

Syarat hubungan kausal antara perbuatan melanggar hukum dan kerugian, untuk menentukan apakah antara perbuatan melanggar hukum dan kerugian ada syarat hubungan kausal, prosedur berikut dapat dilakukan, yaitu: ${ }^{26}$

1) Pertama harus diselidiki apakah perbuatan dalam hubungan dengan kerugian dapat dinilai sebagai syarat yang sedemikian, sehingga tanpa kerugian tidak akan timbul (conditio sine qua non);

2) Kemudian harus dipastikan apakah kerugian itu dianggap sebagai akibat yang wajar diharapkan dari perbuatan melanggar hukum (hubungan adequat). Apabila diantara kedua syarat diatas, salah satunya dapat dibuktikan, maka ada hubungan kausal yang cukup antara perbuatan melanggar hukum dan kerugian.

e. Pelaku tersebut bersalah (kesalahan)

PadaPasal 1365BWmensyaratkan

${ }^{26}$ J.H. Niuwenhuis, Op.Cit, h.131. bahwa orang yang menimbulkan kerugian bertanggung gugat hanya apabila ia bersalah. Syarat kesalahan dalam Pasal 1365 BW menghendaki bahwa disamping tercelanya perbuatan (sifat melanggar hukum), dapat disessalinya pelaku perbuatan itu (kesalahan) merupakan syarat untuk tanggung gugat. ${ }^{27}$ Suatu tindakan dianggap merupakan syarat untuk mengandung unsur kesalahan, sehingga harus bertanggunggugat,jikamemenuhi unsur sebagai berikut. ${ }^{28}$

1. Ada unsur kesengjaan;

2. Ada unsur kelalian (negligence, culpa): dan

3. Tidak ada alasan pembenar atau alasan pemaaf (recht vaardigingsgrond).

Syarat-syarat diatas yang perlu (noodzakelijk) dan secara bersama merupakan syarat yang cukup (veldoende) untuk tanggung gugat berdasarkan Pasal 1465 BW.

Dalam BW mengenai ganti rugi pada perbuatan dalam Pasal 1243 BW sampai Pasal 1252 BW terkait wansprestasi. Ganti rugi dapat berupa ganti rugi, biaya, dan bunga. Selain ganti rugi tersebut, di BW juga menyebutkan pemberian ganti rugi terhadap hal-hal sebagai berikut:

1. Ganti rugi untuk perbuatan melanggar hukum (Pasal 1365 BW);

27 Ibid, h.129.

${ }^{28}$ Munir Fuady, Op. Cit, h.12. 
2. Ganti rugi untuk perbuatan yang dilakukan oleh orang lain (Pasal 1366 BW);

3. Ganti rugi untuk pemilik binatang (Pasal 1369 BW);

4. Ganti rugi untuk pemilik gedung yang ambruk (Pasal 1369 BW);

5. Ganti rugi untuk keluarg yang ditunggalkan oleh orang yang dibunuh (Pasal 1370 BW);

6. Ganti rugi karena orang telah luka atau cacat anggota badan (Pasal 1371 BW); dan

7. Ganti rugi karena tindakan penghinaan (Pasal 1372 dengan Pasal $1380 \mathrm{BW}){ }^{29}$

Dalam ketentuan perbuatan melanggar hukum yang diatur dalam Pasal 1365 BW, membuka kemungkinan pengajukan berbagai gugatan, yaitu: ${ }^{30}$

a. Ganti rugi, lazimnya diberikan dalam bentuk sejumlah uang, tetapi lain halnya dengan ganti rugi pada wanprestaso, kemungkinan ganti rugi dalam bentuk lain terbuka bagi debitor;

b. Pernyataan hukum (verklaring voor recht), penggugat dapat menuntut pernyataan hukum bahwa suatu perbuatan tertentu melanggar hukum. Dalam hal ini, tidak isyaratkan telah ada perbuatan melanggar hukum dan tergugat bersalah atau telah

\footnotetext{
${ }^{29}$ Ibid, h.135.

${ }^{30}$ J.H. Nieuwenhuis, Op. Cit, h.133-134.
}

diderita kerugian tetapi yang diperlukan adalah penggugat berkepentingan atas pernyataan hukum tersebut dan ada ancaman nyata bahwa tergugat akan melakukan perbuatan melanggar hukum; dan

c. Perintah atau larangan hakim. Atas permintaan penggugat, hakim dapat memerintahkan tergugat untuk mengakhiri keadaan melanggar hukum atau melarang ancaman melanggar hukum. Dalam hal ini, perintah ditujuhkan pada pelanggaran kewajiban untuk berbuat. Sedangkan larangan diajukan pada pelanggaran kewajiban untuk berbuat. Disini juga larangan itu dan memang ada ancaman nyata bahwa tergugat akan melakukan perbuatan melanggar hukum.

Tuntutan ganti kerugian akibat perbuatan melanggar hukum dapat berupa ganti rugi materiil (ganti rugi yang nyata telah diderita) maupun ganti rugi immateriil (ganti rugi akibat kehilangan keuntungan yang akan diperoleh di kemudian hari). ${ }^{31}$

\footnotetext{
31 Pemenuhan tuntutan ganti rugi immaterial diserahkan kepada penilian hakim dengan prinsip ex aquo et bono, hal ini yang kemudian menimbulkan kesulitan dalam menentukan besaran kepada immaterial yang akan dikabulkan, sebab tolak ukurnya diserahkan kepada subjektifitas hakim yang memutus. Mahkamah Agung Republik Indonesia memberikan suatu pedoman dalam pemenuhan gugatan ganti rugi immaterial, yaitu dalam Putusan Peninjauan Kembali Nomor 650/PK/ Pdt/1994, tanggal 26 Oktober 1994, yang pada pokoknya hanya dapat diberikan dalam hal-hal tertentu $1372 \mathrm{BW}$, ganti rugi immaterial hanya dapat diberikan dalam halhal tertentu saja seperti perkara kematian, luka berat, dan penghinaan. Yurisprudensi Mahkamah Agung membatasi tuntutan besaran nilai dan jumlah ganti rugi
} 


\section{Badan Hukum.}

Subjek hukum secara hukum perdata dapat berupa orang ${ }^{32}$ dan badan hukum ${ }^{33}$.

antara lain: Putusan Mahkah Agung Republik Indonesia Nomor 196 K/Sip/1974, tanggal 7 Oktober 1976, yang menyatakan" bahwa besarnya jumlah ganti rugi perbuatan melawan hukum, dibatasi pasa prinsip Pasal 1372 BW, yaitu didasari pada penilian kedudukan sosial ekonomi kedua belah pihak. Selain itu Putusan Mahkamah Agung Republik Indonesia Nomor 1226 K/Sip/1977, tanggal 13 April 1978, menyatakan" bahwa soal besarnya ganti rugi pada hakekatnya lebih merupakan soal kelayakan dan kepatuhan yang tidak dapat didekati dengan suatu ukuran. Ibid, h.137.

32 Orang atau manusia sebagia pendukung hak dan kewajiban tidak tergantung pada agama, jenis kelamin, kewarganegraan, miskin dan kaya, karena dalam hukum perdata setiap manusia mempunyai hak yang sama. Setiap orang mempunyai kewenangan berhak, karena ia merupakan subjek hukum, tetapi tidak setiap orang cakap melakukan perbuatan-perbuatan hukum yang disebut merrderjarig. Pada umumnya orang-orang yang disebut merrderjarig dapat melakukan perbuatan-perbuatan hukum secara sah, kecuali jika undang-undang tidak menentukan demikian. Batasan umum seseorang agar dianggap sebagai merrderjarig atau minderjaring tidak sama setiap warganegara, yang diatur dalam Pasal 330 BW. Setiap orang tiada terkecuali sebagai pendukung hak dan kewajiban, namun tidak semuanya cakap untuk melakukan perbuatan hukum (rechsbekwaamheid). Orang yang menurut perundang-undangan dinyatakan tidak cakap untuk melakukan perbuatan hukum adalah:

1. Orang-orang yang belum dewasa, yaitu anak yang beum mencapai umur 18 tahun atau belum pernah melangsungkan perkawinan (Pasal 1330 BW juncto Pasal 17 UU Perkawinan.;

2. Orang-orang yang ditaruh dibawah pengampuuan yaitu orang-orang dewasa tetapi dalam keadaan dungu, gila, mata gelap dan pemboros (Pasal 1330 BW juncto Pasal 433 BW; dan

3. Orang-orang yang dilarang undang-undang untuk melakukan perbuatan-perbuatan hukum tertentu, misalnya orang yang dinyatakan pailit (Pasal 1330 junto UU Kepailitan).

Lihat Riduan Shahrani, Seluk Beluk dan Asas-asas Hukum Perdata, Alumni, Bandung, 200047 dan, Trisadini Prasastinah Usanti, Agus Yudha Hernoko, dan Erni Agustin, Bahan Ajar, 2012, h.6-7.

${ }^{33}$ Badan hukum dapat mempunyai hak dan kewajiban serta dapat pula mengadakan hubungan-hubungan hukum baik dengan badan hukum yang lain maupun dengan subjek hukum manusia, karena itu badan hukum dapat mengadakan perjanjian jual beli, tukar menukar, sewa menyewa, dan segala macam perbuatan dilapangan harta kekayaan. Menurut Pasal 1365 badan hukum dibagi atas tiga (3) macam yaitu:

1. Badanhukum yang diadakan oleh pemerintah, misalnya Daerah Tingkat 1, Daerah Tingkat II, Kotamday, bank-bank yang didirikan oleh negara;

2. Badanhukum yang diakui oleh pemerintah misalnya perkumpulan-perkumpulan, gereja, dan
Badan hukum dapat melakukan perbuatan melawan hukum. Menurut Sri Soedewi Masjcchoen Sofwan, bahwa badan hukum bertindak dalam lalu lintas dengan perantaraan orang-orang yang menjadi alat perlengkapan atau bawahannya (perbedaan antara dua itu akan ditunjuk kembali). ${ }^{34} \mathrm{Hal}$ ini menurutnya sebagaimana lasthebber dapat melakukan perbuatan untuk orang lain, lastgevernya, yang perbuatan itu, sebagimana dinamakan, dipertanggungkan (toegerekend) kepada si lastgever tadi. Kemudian perbuatan-perbuatan, baik yang menurut hukum maupun yang melawan hukum, dari pada orang-orang yang bertindakk untuk suatu badan hukum, dapat dipertanggungkan kepada badan hukum itu. Hal hanya berhubungan dengan kapan masalahitudilakukan. Tidaksemuaperbuatan yang dilakukan oleh alat perlengkapan atau bawahan, dapat dipertanggungkan kepada badan hukumnya, harus ada hubungan tertentu antara perbuatan dan lingkungan pekerjaan alat perlengkapan atau bawahan itu. $^{35}$

organisasi agama dan sebagainya; dan

3. Badanhukum yang didirikan untuk suatu maksud tertentu yang tidak bertentangan dengan undangundang seperti PT, Yayasan, dna Koperasi, Ibid, h.8.

Untuk syarat yang harus dipenuhi oleh suatu badan/ perkumpulan/badan usaha agar dapat dikatakan sebagai badan hukum (rechtpersoon). Menurut dokrin syarat-syarat itu adalah sebagai berikut,: a. Adanya kekayaan yang terpisah;

b. Mempunyai tujuan tertentu;

c. Mempunyai kepentingan sendiri; dan

d. Adanya organisasai yang teratur.

${ }^{34}$ Sri Soedewi Masjcchoen Sofwan, Op. Cit, h.65.

35 Untuk menjelakan, contoh wakil daripada sebuah NV yang untuk perjalanan-perjalanannya dalam dinas NV yang dapat memakai sebuah mobilm dapat pula mempergunakan mobil itu untuk keperluan prive, tetapi dalam hal terakhir ini ia tidak lagi memiliki NV tersebut. Jika terjadi kecelakaan, maka akibat-akibat yang merugikan pihak ketiga hanya dipertanggungkan kepada $\mathrm{NV}$, apabula si wakil itu sedang mengadakan perjalanan 
Dalam perkembanganya Pasal 1365 mengenal badan hukum yang turut serta dengan perantara alat-alat pelengkapnya, organ-organnya, yaitu orang-orang yang diberi wewenag berbuat untuk clan atas nama badan hukum tersebut. Demikian alatalat perlengkapan yang berbat untuk dan atas nama perseroaan terbatas yakni direkturnya, untuk clan atas nama propinsi gubernurnya. Disamping alat-alat perlengkapan baik P.T. maupun propinsi itu mempunyai pegawaipegawai yang tidak merupakan alat-alat perlengkapan. ${ }^{36}$

Dalam perseroan terbatas, mengalami kerugian atau kepailitan, terkaiat dengan pertanggungjawaban dalam perkara yang mengarah ganti rugi, misal dapat ditemukan dalam Undang Undang Nomor 40 Tahun 2007 tentang Perseroan Terbatas. ${ }^{37}$ Dalam

dinas, tidak apabila ia pada sesuatu hari minggu bertamasya beserta keluarga untuk tanggung gugatnya badan hukum diperlukan. Dalam hal ini jika mengenai alat pelengkap: bahwa dilakukan perbuatan didalam lingkungan formil dari pada kewenangannya, dan mengenai bawahanya (periksa pasal 1367 ayat (3) BW, bahwa kerugiannya disebutkan didalam pekerjaan-pekerjaan yang merka dipakainya" (oleh atasnya). Periksa tentang Pasal 1367 lebih lannjut Nomor 316. Disini ada perbedaan antara "alat perlengkapan" (orgaan) dan bawahaan (ondergeschikte). Yang dinamakan alat perlengkapan apabila mengenai wakil-wakil yang fungsinya lebih berdiri sendir, yakni dalam arti bahwa cara melakukan tugasnya dan cara bertindak untuk badan hukum sebagiann besar diserahkan kepada mereka itu sendiri, sekalipun hal itu harus dilakukan dalam batasbatas yang tertarik oleh undang-undang, anggaran dasar atau peraturan-peraturan dan sebagainya, yang harus diperhatikan kepada pengurus NV, walikoota dari pada kotrapraja dan sebagainya. Untuk wakil yang bukan alat perlengkapan mempunyai kedudukan yang lebih rendah, ia harus bertindak menurut petunjuk-petunjuk daripda atasnnya. Ibid, h.66.

${ }^{36}$ Soetojo Prawirohamidjojo, Perbuatan Melanggar Hukum Oleh Pengusaha (Onrechtmatige Overheidaad) . dalam Perkembangan Dan Dinamika Hukum PerdataIndonesia: dalam rangka peringakan ulang tahun ke-80, Prof DR.MR R. Soetojo Prawirohamidjojo, Lutfansah Mediatama, Surabaya, 2009, 52.

37 Disebutkan "anggota direksi dan anggota dewan komisaris telah tidak melaksanakan tugas dan kewajibannya dengan etikat baik dan penuh tanggungjawab, sehingga pertanggujawaban di UUPT mengadopsi asas-asas company law yang dianut dalam negara-negara common law system. $^{38}$ Pertanggungjawaban dalam UU PT, menjadi pedoman dalam terjadi pencemaran lingkungan.

\section{Tanggung gugat perusahaan pertambangan batubara Terhadap pencemaran lingkungan}

Tanggung gugat untuk lingkungan hidup, di Indonesia dikenal dengan tanggung gugat mutlak yang mulai dikenal/

perseroaan mengalami kerugian atau kepailitan sampai hal itu dapat dibuktikan sebaliknya oleh anggota direksi dan anggota dewan komisaris. Penafsiran berbeda dengan yang dianut business judgment rule, menyatakan" direksi (board of directors) dianggap telah melaksanakan tugasnya dengan penuh tanggung jawab dan berikat baik serta untuk kepentingan perseroaan sampai dapat dibuktikan sebaliknya oleh penggugat, didalam yurispenden pengadilan Amerika Serikat dalam perkara Francis V United Jersey Bank, 532 A.2.d 814 (N.J.1981) menawarakn pedoman bagi direksi perseroaan agar tidak dianggap melangar judgment rule, lihat Sudikno Mertokusuma, Penemuan Hukum dan Etika Profesi, dalam Soetojo Prawirohamidjojo, Perbuatan Melanggar Hukum Oleh Pengusaha (Onrechtmatige Overheidaad) . dalam Perkembangan Dan Dinamika Hukum PerdataIndonesia: dalam rangka peringakan ulang tahun ke-80, Prof DR.MR R. Soetojo Prawirohamidjojo, Lutfansah Mediatama, Surabaya, 2009, h. 60.

38 Dalam asas-asas common law system, ada 2 (dua) dokrin) dalam pertanggungjawaban yakni

1. Doctrine of ultra vires bertolak dari pemahaman selain tugas-tugas dan kewajiban-kewajiban yang ditentukan oleh undang-undang, yang disebut statutory duties, pada anggota direksi juga harus melaksanakan tugas-tugas dan kewajiban fiduciary duties. Konsekuensi dari perbuatan yang ultra vires, baik perbuatan yang melampau wewenang maupun yang tidak sesuai dengan maksuddan tujuan perseroan tetapi mengingat pibadi anggota direksi yang melakukan perbuatan hukum itu, lihat Robet R. Rennington, Company Law, Fifth Editon, London; Butterworth, 1985, h.659. ibid, h. 81.

2. ${ }^{D}$ octrine of duty of care, bahwa anggota direksi dan anggota dewan komisaris memilliki duty of care dalam melaksanakan tugas dan kewajibannya, yaitu kewajiban untuk memberikan keperdulian seoptimal mungkin kepada kepentingan perseoraan sesuai dengan maksud dan tujuan perseroan dan melaksanakan dengan itakat baik., ibid, h. 82 . 
diatur secara tegas dalam UU No.4 Tahun 1982 tentang Ketentuan-ketentuan Pokok pengelolaan Lingkungan Hidup, dan masih dipertahankan UU No.23 Tahun 1997 tentang Pengelolaan lingkungan hidup dan UU No.32 Tahun 2009 tentang Perlindungan dan Pengelolaan Lingkungan Hidup atau (PPLH).

Pasal 1 angkat 14 UU No.32 Tahun 2009 tentang PPLH, pencemaran lingkungan adalah masuk atau dimasukannya makhluk hidup, zat, energi, dan/atau komponen lain ke dalam lingkungan hidup yang ditetapkan. Perusakan lingkungan hidup adalah tindakan orang yang menimbulkan perbuhaan langsung atau tidak langsung terhadap sifak fisik, kimia, dan/atau hayati lingkungan hidup, sehingga melampaui kriteria baku kerusakan lingkungan hidup (Pasal 1 angkat 16 UUPPLH). Akibat pencemaran lingkungan dan perusakan lingkungan hidup, inilah yang menjadi dasar adanya gugatan dalam sengketa lingkungan lingkungan. Tanpa adanya pencemaran/ kerusakan lingkungan hidup, tidak ada gugatan sengketa lingkungan. Subjek dalam gugatan sengketa lingkungan adalah pelaku pencemaran dan/atau perusakan lingkungan atau pencemar dan//atau perusak lingkungan sebagai pihak tergugat serta penderita atau korban pencemaran dan/atau perusakan lingkungan sebagai penggugat.

Penggugat dalam masalah percemaran dan/atau perusakaan lingkungan hidup, yang dituntut ganti kerugian. Dalam Pasal Pasal 87 ayat (1) UUPPLH, menyatakan “ setiap penanggung jawan kegiatan/usaha melakukan perbuatan melawan hukum berupa pencemaran dan/atau perusakan lingkungan hidup yang menimbulkan kerugian pada orang lain atau lingkungan hidup wajib memikul ganti rugi dan/atau tindakan tertentu." Essensi dari Pasal 87 ayat (2) UUPPLH, sudah ditentukan pihak yang bertanggungjawan secara yuridis dalam gugatan sengketa lingkungan, yaitu setiap penanggung jawab usaha dan/atau kegiatan dan setiap orang yang melakukan pemindahantangan, pengubahaan sifat dan bentuk usaha, dan/atau kegiatan dari suatu badan usaha yang menyebabkan terjadinya pencemaran lingkungan. ${ }^{39}$ Secara yuridis ketentuan Pasal 87 ayat (1) UUPPLH tidak mengatur lebih lanjut mengenai tata cara menggungat ganti kerugian, sehingga berlaku Pasal 1365 BW.

Untuk memperoleh ganti kerugan berdasarkan Pasal 1356 BW, menurut Lambers, harus memenuhi persyaratan sebagai berikut:

a. Perbuatan harus bersifat melawan hukum;

b. Pelaku harus bersalah;

c. Ada kerugian; dan

d. Ada hubungan sebab akibat antara

39 Aan Efendi, Penyelesain Sengketa Lingkungan, Mandar Maju, Bandung, 2012, h.26. dijelaskan bagi siapa saja yang melakukan perbuatan pencemaran lingkungan meskipun tidak disebutkan oleh Pasal 87 ayat (1) dan (2) UUPPLH. Menurut Wirjono Prodjodikoro, Perbuatan Melanggar Hukum, Mandar Maju, Bandung, 2000, h.7. mengemukakan perbuatan melanggar hukum tidak hanya dimaknai secara sempit sebagai perbuatann yang melanggara peraturan perundang-undangan. Perbuatan melanggar hukum juga termasuk perbuatan pergaulan hidup masyarakat. Tidak semua perbuatan melanggar hukum dapat melahirkan sengketa lingkungan. secara lebih spesifik perbuatan melanggar hukum yang menjadi dasar gugatan sengketa lingkungan. 
perbuatan dengan kerugian. ${ }^{40}$

Dalam Pasal 1365 BW, khususnya unsur kesalahan pelaku dan hubungan kausal antara perbuatan pelaku dengan kerugian. Untuk beban pembuktian ada pada pihak penggugat: Setiap orang yang mendalihkan bahwa ia mempunya hak, atau guna meneguhkan haknya sendiri maupun membantah suatu hak orang lain, menunjuk pada suatu peristiwa, diwajibkan membuktikan adanya hak atau peristiwa tersebut.

Pasal 1365 BW, menganut konsep " tanggung gugat berdasarkan kesalahan atau (schulanprakelijkheid) yang dapat dipersamakan dengan asas liability base on fault (tot liability) dalam sistem hukum Anglo-Amerika, sehingga timbul masalah mengenai pembuktian unsur kesalahan bagi penggugat atau penderita. ${ }^{41}$ Siti Sundari mengemukakan:

Di dalam kasus pencemaran lingkungan, penderita/korban berada pada posisi sosial yang relatif lemah dan awam soal hukum, berhadapan dengan satu atau sejumlah pencemar dengan kekuatan ekonomi yang tangguh. Kekuatan para pihak yang tidak seimbang, ketidakpastian akan berhasil dan resiko biaya yang tinggi seringkali menimbulkan keengganan bagi korban untuk berperkara/menggugat di

${ }^{40}$ Siti Sundari Rangkuti, Hukum Lingkungna dan Kebijaksanaan Lingkungan Nasional, Edisi Ketiga, Airlanggar Universitas Press, Surabaya, 2005, h.289.

${ }^{41}$ Siti Sundari Rangkuti, Inovasi Hukum Lingkungan; Dari Ius Constitutum ke Ius Constituendum, pidatp pengukuhan diucapkan dihadapan rapat senat Universitas Airlangga Surabaya saat penerimaan Jabatan Guru Besar pada Fakultasa Hukum Universitas Airlangga di Surabaya, Hari Sabtu, tanggal 11 mei 1991, h.13. lihat pengadilan. ${ }^{42}$

Tanggung gugat berdasarkan kesalahan, dalam penerapannya menimbukan berbagai masalah antara lain:

Membuktikan adanya kesalahan tidaklah mudah karean harus lebih dahulu dibuktikan adanya hubungan sebab akibat (causality) antara perbuatan pencemaran dengan kerugian dari si penderita. Khususnya bagi lingkungan hidup hal membuktikan atau menjelaskan hubungan sebab akibat dari perbuatan si poluter dengan korban, merupakan hak yang sangat sulit sekali. Menganalisis suatu pencemaran membuktikan penjelasan yang bersifat ilmiah, bersifat teknis, dan bersifat khusus, sehingga buktikan sebab akibat dalam kasu pencemaran justru lebih menyulitkan pula. Oleh karena itu bila menerapkan sistem pertanggungjawaban bersifat biasa tidaklah mencerminkan rasa keadilan karena korban disini mengalami kerugian ganda (double victim), yakni ia sudah sebagai korban dan juga berkewajiban pula membuktikan adanya fault atau men rea dari pelaku. ${ }^{43}$ Konsep Pasal 1365 BW dengan tanggung gugat berdasarkan kesalahan, mengalami berbagai masalah seperti diatas, UUPPLH memperkenal konsep tanggung gugat mutlak (ricisoaansprakelijkheid) atau yang dalam sistem hukum Anglo Amerika disebut sebagai asas strict liabilty. ${ }^{44}$ Dengan asas

42 Ibid.

43 N.h.T.Siahaan, Hukum Lingkungan, Pancuran Alam, Jakarta, 2006, h.274-275.

44 UUPPLH menggunakan istilah tanggung jawab mutlak untuk menyebut konsep taggung gugat mutlak, namun terdapat kecenderungan dikalangan ahli hukum perdata untuk memaknai istilah liability untuk membedakan dari istilah verantwoordelijkheid atau responsibility yaitu tanggungjawab yang lebih dikenal dalam hukum pidana. 
tanggung gugat mutlak penggugat tidak perlu lagi membuktikan unsur kesalahan tergugat, tanggung gugat timbul seketika pada saat terjadinya perbuatan.

Prinsip tanggung gugat mutlak (no fault liability or liability without fault), ${ }^{45}$ pada prinsipnya dimaksud tanggung gugat keharusan untuk membuktikan adanya kesalahan. ${ }^{46}$ Dalam bidang lingkungan, termasuk dalam hal ini bidang pertambangan batubara, asas tanggung gugat mutlak dikenal seiring dengan begitu rumit (complicated) mengenai aspek tanggung jawab perdata dibidang lingkungan. beberapa faktor kesulitan mengindentifikasi luasan kerusakan/pencemaran lingkungan yang menjadi obyek tanggung jawab terkait beberapa faktor. ${ }^{47}$

Istilah tanggung gugat sudah digunakan dalam seminarr hukum dan asuransi, tahun 1978 di Padang, lihat di Siti sundari Rangkuti, Op. Cip, h.287.

${ }^{45}$ Didalam perpustakaan biasanya dikenal dengan ungkapan atau istilah absolute liability atau strict liability. Istilah stric liability pertama kali dikemukakan oleh W.H. Winfield pada tahun 1926 dalam sebuah artikel yang berjudul “ The Myth of Absolute Liability, sedangkan istilah absollute liability dipergunakan pertama kali oleh John Salmond dalam buku yang berjudul ' The Law of Torts, pada tahun 1907.Lihat E.. Saefullah Wiradipraja, Tanggung Jawab Pengangkut Dalam Hukum Pengangkutan Udara Internasional dan Nasional, Liberty, Yogjakarta, 1989, h. 35. Aan efendi, Ibid, h.30.

${ }^{46}$ Dengan kata lain, suatu prinsip tanggung gugat yang memandang kesalahan sebagia suatu yang tidak relavan untuk permasalahakan apakah pada kenyataan ada atau tidak, Ibid. lain:

47 Obyek tanggung jawab ada beberapa faktor antara

1. Menulusuri aspek kualitas dari kasus kerusakan pencemaran lingkungna tidaklah mudah karena media-media penyebab pencemarean/perusakan lingkungan (substances) bisa sangat khusus dan toksis;

2. sifat kerusakan tergantung pada media lingkungan yang tercemar atua rusak, jadi ada karekter lingkungan yang spesifik dan tidak bersifat mendasar (general);

3. sifat proses bekerjanya media-media penyebab pencemarean ada yang menimbulkan akibat seketika (direct effect), tetapi tidak jarang pula
Dalam kaitan dengan sengketa lingkungan, termasuk bidang pertambangan batubara, tanggung gugat dalam sengketa, untuk itu mutlak diperlukan untuk menciptkan rasa keadilan bagi korban yang manjadi korban pencemaran perusakan lingkungan hidup, hal mengingat korban pencemar-perusak adalah masyarakat awam dan ekonomi lemah, sedangkan pelaku pencemaran-perusakan lingkungan adalah perusahaan-perusahaan yang puya kekuatan ekonomi yang kuat. Untuk sosialisasi dan penegakan hukum harus dapat memberi rasa keadilan bagi mereka yang terkena dampak pengelolaan pertambangan, terkait percemaran/ kerusakan lingkungan.

Untuk tanggung gugat mutlak diatur dalam Pasal 88 UUPPLH, disebutkan:

Setiap orang yang tindakannya, usahanya, dan/atau kegiatannya mengggunakan B3, menghasilkan dan/ atau mengelola limbah B3, dan/atau yang menimbulkan ancaman serius terhadap lingkungan hidup bertanggungjawab mutlak atas kerugian yang terjadi tanpa pembuktian unsur kesalahan

DalamPasal88UUPPLH, asastanggung gugat mutlak tidak diterapkan terhadap semua jenis sengket lingkungan, termasuk dalam bidang pertambangan batubara. Asas tanggung gugat mutlak baru diterapkan terhadap sengketa lingkungan akibat suatu

bersifat kemudian (long term effect), artianya baru diketahui setelah lama berselang, misalnya setelah setahun; dan

4. Terkait pula kepada faktor-faktor perubahan ekologis (ecological effect) yang memperlukan pengetahuan teknis. Lihat .H.T.Siahaan, $O p$. Cip.h .275. Aan Efendi, Ibid, h.30-31. 
usaha dan/atua kegiatan: a) menggunakan B3, b) menghasilkan dan/atua mengelola limbah B3, dan c) menimbulkan ancaman serius terhadap lingkungan. ${ }^{48}$ UUPPLH tidak mengatur secara tegas kriteria yang menimbulkan serius terhadap lingkungan.

Pasal 22 ayat (2) UUPPLH menetapkan kreteria usaha dan/atau kegiatan yang berdampak penting terhadap lingkungan adalah:

a. Besarnya jumlah penduduk yang akan terkena dampak rencana usaha dan/atau kegiatan;

b. Luas wilayah penyebaran dampak;

c. Intensitas berlangsung dan lamanya dampak;

d. Banyaknya komponen lingkungan hidup lain yang akan terkena dampak;

e. Sifat kumulatif dampak;

f. Berbalik dan/atau tidak berbaliknya dampak; dan

g. Kreteria lain perkembangan lain sesuai perkembangan ilmu pengetahuan dan teknologi.

Dengan demikian makna Pasal 22 ayat (2) UUPPLH, tidak secara signifikat

${ }^{48}$ B3 merupakan bahan berbahaya dan beracun. Mengenai usaha dan/atau kegiatan yang menggunaka bahan bahaya dan beracun dijelaskan pada Pasal 1 angkat 21 UUPPLH: bahan bahaya dan beracun, atau B3 adalah zat, energi, dan/atau komponen langsung karena sifat, konsentrasi, dna /atau jumlahnya, baik secara langsung atau tidak langsung, dapat mencemarkan dan/atau merusak lingkungan hidup, dan/atau membahayakan lingkungan hidup, kesehatan, serta keberlangsungan hidup manusia dan makhluk hidup lain. Sedangkan limbah bahan bahaya beracun atau limbah B3 adalah sisa suatu usaha dan/ atau kegiatan yang mengandung B3, Pasal 1 angkat 22 UUPPLH. mengarah pada kretia B3 sebagai bahan bahaya dan beracun.

Penerapan asas tanggung gugat mutlak biasanya didampingi dengan ketentuan beban pembuktian terbalik (omkering der bewijslast), kewajiban asuransi dan pembuktian plafond (ceiling) yaitu batas maksimum ganti kerugian. ${ }^{49} \mathrm{UUPPLH}$ tidak memberi pengaturan tentang beban pembuktian terbalik dan kewajiban asuransi. ${ }^{50}$ UUPPLH hanya menetapkan batas maksimum ganti rugi sebagaimana ditentukan dalam penjelasan Pasal 88 UUPPLH menyebutkan:

Pengertian bertanggungjawab secara mutlak atau strick liability adalah unsur kesalahan tidak perlu dibuktikan oleh pihak penggugat sebagai dasar pembayaran ganti kerugian. Ketentuan ayat ini merupakan lex specialis dalam gugatann tentang perbuatan melanggar hukum pada umumnya. Besarnya nilai ganti rugi yang dapat dibebankan terhadap pencemaran atau perusak lingkungan hidup menuruut pasal ini dapat ditetapkan sampai batas tertentu. Yang

49 Siti Sundari Rangkuti, Hukum Lingkungan dan Kebijaksanaan Lingkungan, Airlangga Press Surabaya, 2005, h.290.

${ }^{50}$ Sedangkan di UU No.23 Tahun 1997 tentang Pengelolaan Lingkungan Hidup, sebelum UUPPLH, Pasal 35 ayat (2) yang menetapkan: "penanggung jawan usaha dan/atau kegiatan dapat dibebaskan dari kewajiban membayar ganti rugi sebagaimana dimaksud pada ayat (1) jika yang bersangkutan dapat membuktikan bahwa pencemar dan/atau perusakan lingkungan hidup disebabkan salah satu alasan sebagai berikut: a) adanya bencana alam atau peperangan; dan b) adanya keadaan terpaksa diluar kemampuan manusia, c) adanya tindakan pihak ketiga yang menyebabkan terjadinya pencemaran dan/atau perusakan lingkungan hidup. Pasal 35 ayat (2) UU PLH, sifanya alternatif dan kumlatif dengan demikian cukup dibuktikan salah satu saja dan tidak semua alasan sudah bisa dipergunakan sebagai dasar untuk menghindari pembayaran ganti rugi yang diatur dlaam Pasal 35 ayat (1) UU PLH. 
dimaksud" sampai batas waktu tertentu" adalah jika menurut penetapan peraturan perundang-undangan ditentukan keharusan asuransi bagi usaha dan/atau kegiatan yang bersangkutan atau telah tersedia dana lingkungan hidup.

Dari rumusan penjelasan Pasal 88 UUPPLH diatas sama dengan rumusan penjelasan Pasal 35 ayat (1) UUPLH. Yang menjadi masalah adalah UUPPLH tidak mengatur beban pembuktikan terhadap perbuatan melanggar hukum. Hal ini dapat menimbulkan rasa ketidakadilan bagi pelaku usaha dan/atau kegiatan yang kegiatannya yang memenuhi ketentuan Pasal 88 UU PPLH. Upaya pembuktian terbalik dalam rangka mengimbangi diterapkan tanggung gugat mutlak itu sendiri. Tujuan dari tanggung gugat mutlak adalah perlindungan bagi korban pencemaran-pencemaran lingkungan, sedangkan beban pembuktian terbalik adalah perlindungan bagi pelaku usaha dan /atau kegiatan usaha dan/atau kegiatannya memenuhi ketentuan Pasal 88 UUPPLH. Menurut Aan Efendi, ${ }^{51}$ tujuan UUPPLH yang hendak memperbaiki atau menyempurnakan UUPLH tidak teralisasi atau bahkan dapat dikatakan mengalami kegagalan.

Dalam ketentuan secara subtansi UU Minerba, tidak mengatur terkait dengan gantirugi terhadap pencemaran yang disebabkan ada pengelolaan pertambangan batubara. UU Minerba secara umum bersifat pengaturan terhadap pertambangan terkait proses perijinan,

\footnotetext{
${ }^{51}$ Aan Efendi, Ibid, h.38.
}

jenis pertambangan and prosedurnya. Pada ketentuan pidana, juga tidak diatur makanisme gantirugi, ketentuan pidana mengatur terkait sanksi terhadap perizinan yang dilakukan. Untuk pertanggungjawab bagi pengusaha dalam hal pemegang izin perusahaan yang berbadan hukum, dapat dikenai ketentuan pidana, yang diatur dalam Pasal 164 UU Minerba yang menyatakan: (1) dalam hal tindak pidana sebagaimana dimaksud dalam bab ini dilakukan oleh suatu badanhukum, selain pidan penjara dan denda terhadap pengurusnya, pidana yang dapat dijatuhkan terhadap badan hukum tersebut berupa pidana denda dengan pemberatan ditambah $1 / 3$ (satu pertiga) kali dari ketentuan maksimum pidana denda yang dijatuhkan.

(2) selain pidana denda sebagaimana dimaksud pada ayat (1), badan hukum dapat dijatuhi pidana tambahan berupa:

a. pencabutan izin usaha; dan/atau;

b. pencabutan status badan hukum.

Pencemaran lingkungan yang timbul dari aktivitas pertambangan batubara, memiliki dampak yang sama terhadap perikehidupan masyarakat sekitar pertambangan. Masyarakat yang dirugikan sebagian kepentingannya sebagia manusia, dalam wujud mengancam kesehatan, merusak sumber daya lingkungan, mengurangi jumlah aset-aset ekonomi, dan menurunkan mutu tata ekologis yang ada. UU Minerba dan UUPPLH, tidak mengatur masalah gantirugi, untuk menentukan siapa yang telah melakukan perbuatan melawan hukum, merujuk Pasal 1243 BW dan Pasal 
1365 BW, dalam pasal tersebut, unsur kesalahan bersifat menentukan tanggung gugat terhadap pencemaran terjadi pencemaran pertambangan batubara. Ini berarti bila tidak terbukti adanya kesalahan tidak ada kewajiban untuk memberi ganti rugi terhadap perbuatan pencemaran yang dilakukan. ${ }^{52}$ Proses tanggung gugat terhadap pengusaha pertambangan dapat mengajukan gugatan ke Pengadilan Negeri, untuk menuntut Ganti rugi.

Dalam hubungan dengan tanggung gugat perusahaan pertambangan batubara terhadap pencemaran lingkungan, ada beberapa karekteryang mendasar. Perbedaan yang dimaksud disini ialah perbedaan karekter pertanggungjawaban atas kerugiankerugian yang timbul akibat pencemaran lingkungan hidup, baik yang timbulkan karena aktivitas manusia maupun proses alam sendiri. ${ }^{53}$ Tanggung gugat perusahaan pertambangan batubara dalam terkait pencemaran lingkungan akibat aktivitas pertambangan, merujuk pada tangung jawab perusahaan unttuk memberi gantirugi. Secara hukum mekanisme yang ditempuh

${ }^{52}$ Terkait dengan pembuktian terhadap perbuatan melawan hukum terhadap pencemaran pertambangan batubara, menurut Pasal 1865 disebutkan, bahwa" barang siapa mengajukan peristiwa atasnama ia mendasarkan sesuatu hak, diwajibakan membuktikan peristiwa-peristiwa itu, sebaliknya barang siapa apa mengajukan peristiwaperistiwa guna membantah hak orang lain, diwajibkan untuk membuktikan peristiwa-peristiwa itu" asas ini dinilai memberatkan pihak yang melakukan gugatan, karena untuk melakukan tuntutan gantirugi pihak penggugat harus bisa membuktikan adanya unsur kesalahan kepada pihak tergugat.

53 Pencemaran lingkungan akibat perbuatan manusia, maka pertanggungjawaban pencemaran terjadi, antara karena perbuata manusia yang melakukan penambangan batubara . dalam hal ini bisa pemilik atau pemegang izin usaha pertambangan diminta pertambangan. Sedangkan pencemaran lingkungan akibat alam, maka pertambangan tidak bisa dibebankan pada pengusaha. melalui Pengadilan Negeri setempat untuk menuntut ganti rugi pada pengusaha. Dalam UUPPLH, terkait Pengusaha, yang merupakan badan hukum diatur dalam Pasal 116 PPLH menyatakan:

(1) Apabila tindak pidana lingkungan hidup dilakukan oleh atau atas nama badan hukum, tuntutan pidana dan sanksi pidana dijatuhkan kepada:

a. Badan hukum; dan /atau

b. Orang yang member perintah untuk melakukan tindak pidana tersebut atau orang yang bertindak sebagai pemimpin kegiatan dalam tindak pidana tersebut.

(2) Apabila tindak pidana lingkungan hidup sebagaimana dimaksud pada ayat (1) dilakukan oleh orang, yang berdasarkan hubungan kerja atau berdasarkan hubungan lain yang bertindak dalam lingkup kerja badan usaha, sanksi pidnaa dijatuhkan terhadap pemberi perintah atau pemimpin dalam tindak pidan tersebut tanpa memperhatikan tindak pidana tersebut dilakukan secara sendiri atau bersama-sama.

Terkait pelaku tanggung gugat perusahaan batubara, dalam hal ini berbentuk badan hukum. Di dalam UUPPLH pemberi perintah atau pimpinan bisa dikenai, seperti dinyatakan 117 UUPPLH sebagai berikut:

Jika tuntutan pidana diajukan kepada pemberi perintah atau pemimpin tindak pidana sebagaimana dimaksud dalam Pasal 116 ayat (1) huruf $b$, ancaman pidana yang 
dijatuhkan berupa tindak pidana penjara dan denda diperberat dengan sepertiga.

\section{Pasal 118 UUPPLH}

Terhadap tindak pidana sebagaimana dimaksud dalam Pasal 116 ayat (1) huruf a, sanksi pidana dijatuhkan kepada badan usaha yang diwakili oleh pengurus yang berwenang mewakili didalam dan diluar pengadilan sesuai dengan peraturan perundang-undangan selaku pelaku fungsional.

\section{Pasal 119 UUPPLH}

Selain pidana sebagaimana dimaksud dalam undang-undang ini, terhadap badan usaha dapat dikenakan pidana tambahahan atau tindakan tata tertib berupa:

\section{a. Perampasan keuntungan yang diperoleh dari tindak pidana;}

b. Penutupan seluruh atau sebagai tempat usaha dan/atau kegiatan;

c. Perbaikan akibat tindak pidana;

d. Pewajiban mengerjakan apa yang dilalaikan tanpa hak; dan/atau

e. Penempatan perusahaan dibawah pengampuan paling lama 3 (tiga) tahun.

Untuk Pasal 120 dan Pasal 121, terkait badan hukum, dalam proses dari kejaksaan berkoordinasi dengan instasi yang bertanggungjawab dibidang perlindungan dan pengelolaan lingkungan hidup untuk melaksanaka eksekusi. Terkait Pasal 119 huruf e, pemerintah berwenang untuk mengelola badan usaha yang dijatuhi sanksi penempatan dibawah pengampuan untuk melaksanakan putusan pengadilan yang telah berkuatan hukum tetap. Dalam penjelasan Pasal 118 UUPPLH, yang dimaksud dengan pelaku fungsional dalam pasal ini adalah badan usaha dan badan hukum. Tuntutan pidana dikenakan terhadap pimpinan badan hukum dan badan usaha karena tindak pidana badan usaha dan badan hukum adalah tindak pidana fungsional, sehingga pidana dikenakan dan sanksi dijatuhkan kepada mereka yang memiliki kewenangan terhadap pelaku fisik dan menerima tindakan pelaku fisik tersebut. Yang dimaksud dengan menerima tindakan dalam pasal ini termasuk menyetujui, atau tidak cukup melakukan pengawasan terhadap tindakan pelaku fisik, dan/atau memiliki kebijakan yang memungkinkan terjadinya tindak pidana tersebut. Tanggung gugat akibat pertambangan, dapat dilakukan pada badanhukum, yakni perusahaan yang mendapat Izin Usaha Pertambangan telah melakukan perusakan/pencemaran. Tanggung gugatperdata, dalam halini berupa tuntutan ganti rugi atas dasar perbuatan melanggar hokum yang dilakukan oleh perusahaan terhadap kerusakan/pencemaran lingkungana kibat pertambangan batubara dapat dilakukan dipengadilan negari tempat perkara.

\section{Kesimpulan}

$\begin{gathered}\text { Tanggung gugat } \\ \text { perusahaan } \\ \text { pertambangan } \\ \text { batubara }\end{gathered}$ Terhadap
pencemaran lingkungan, dalam UU No.32
Tahun 2009 tentang Perlindungan dan


Pengelolaan Lingkungan Hidup, dikenal dengan tanggung gugat mutlak yang berbentuk ganti rugi, dengan prosesnya melalui Pengadilan Tinggi Setempat. Perusahaan batubara yang mengakibatkan pencemaran lingkungan dapat dikenai pertanggujawaban yang diatur dalam Pasal 116-119 UUPLH, sedangkan UU Minerba, terkait perusahaan, hanya mengatur tindak pidana dalam pengaturan perizinan tambang. untuk pertanggung gugat perdata untuk menuntut gantirugi melalui Pengadilan negeri.

\section{DAFTAR BACAAN}

Agustina, Rosa, Perbuatan melawan hukum, Desertasi Fakultas Hukum Univeritas Indonesian, Jakarta, 2003.

Basuki, Nur, Penyalahgunaan wewenanng dalam pengelolaan keuangan Daerah yang berimplikasi tindak pidana korupsi, Disertasi, Pasca Sarjana Universitas Airlangga Surabaya. 2006.

Campbell Black, Henry, Black's Law Dictionary, West Publishing, Co.St, Paul Minnessotta, 1990.

Efendi, Aan Penyelesain Sengketa Lingkungan, Mandar Maju, Bandung, 2012.

Fuady, Munir Perbuatan Melawan Hukum, Citra Aditya Bakti, Bandung, 2002.

Friendman, Lawrence M. Law and Society. An Introduction Englewood Cliffs, N.J. Prentice Hall, 1977.

George W, Rock, Mining Enviroment and Development, A Series of Paper
Prepared for the United Nations Conference on Trade and Development (UNCTAD), 2005.

Hadjon, , Philipus M. Perlindungungan Hukum Bagi Rakyat, Peradapan, 2000.

Harjasoemantri, Koesnadi, Hukum Tata Lingkungan, Edisi ketujuh, Cetakan Ketujuhbelas, Gajahmada Universitas Press, Yogjakrta, 1999.

Head, John W, Pengantar Umum Hukum Ekonomi, Edisi Bahasa Indonesia dan Inggris, ELIPS, Jakarta, 1997.

Hatrik, HamzahAsas Pertanggungjawab Korporasi Dalam Hukum Pidana Indonesia (Strict Liability dan Vicarious Liability), Raja Grafindo Persada, 1995.

Kleden, Ignas Kearah Pembangunan Bekelanjutan di Indonesia, dalam Buku pembangunan berkelanjutan, mencari format politik, Yayasan SPEDS, Gramedia Pustaka Utama Bekerjasama dengan Yayasan SIPES, Jakarta, 1992.

Komisi Dunia Untuk Lingkungan dan Pembangunan (WCED).

Kerap, Sonny, dalam Proceedings of Ninth Internasional Coral Reef Sysmsium, Bali, 23-27 Oktober 2000, Indonesia Institute of Science, Internasional Society for Regal Studies, 2002.

Masjcchoen Sofwan, Sri Soedewi Hukum Perdata; Hukum Perutangan, Bagian B, Seksi Hukum Perdata Fakultas Hukum Univeriverstas Gajah Madha, Yogjakarta, 1980.

Nieuwenhuis, J.H, Hoofdstuken verbintenissenrecht, terjemahan Djasadin Saragih, Surabaya, 1985. 